\title{
The effect of sucrose and 8-hydroxyquinoline sulphate (8-HQS) on keeping qualities of bud-cut Chrysanthemum flowers and the level of reducing sugars in the florets
}

\section{ALEKSANDRA LUKASZEWSKA}

Department of Ornamental Plants, Faculty of Horticulture, Warsaw Agricultural University, ul. Nawoursynowska 166, 02-766 Warszawa, Poland

(Received: February 24, 1979)

\begin{abstract}
Chrysanthemums harvested as buds of $50-60 \mathrm{~mm}$ in diameter and held in the solutions of sucrose and 8-HQS had inflorescences of quality equal to those opened on the plant and better than flowers placed in water. Exogenous sucrose prolonged vase-life of cv. 'Bronze Bornholm' but did not affect cv. 'Crimson Robe'. No difference was observed in the quality of flowers placed in different sucrose concentrations. All the solutions which improved keeping qualities of cut chrysanthemums caused considerable increase in the flower fresh and dry matter. Also an increase in reducing sugars was found in flowers of both cultivars held in the solutions of sucrose and 8-HQS.
\end{abstract}

\section{INTRODUCTION}

Recently a new method of harvesting cut flowers in immature buds and opening them in special solutions has been introduced. Successful trials have been made with chrysanthemums (Marousky, 1969, 1973), gladioli (Ma yak et al., 1973), dahlias (Ł ukaszewska, 1978), carnations (C y w ińs k a - S m o t e r et al., 1978).

Chrysanthemums are the third major crop in Poland grown for cut flowers under covers. Harvesting, handling and shipping of chrysanthemums cut in buds would increase handling efficiency and reduce risk of damage as well as labor and transportation costs. Since most of the works done on chrysanthemums have been made either on spray chrysanthemums (M a rousky, 1969; G a and Nichols, 1977) or on the standard cultivars rarely grown in Poland ( $\mathrm{M}$ a r o u sky, 1973) the investigations were undertaken on two commonly grown cultivars to check a possibility of harvesting them in an immature stage. As an increase in soluble sugar level in the flowers might be in- 
volved in the bud opening favouring water uptake (A a r ts, 1957) and promoting cell enlargement and since exhaustion of carbohydrates is an important cause of senescence in cut flowers ( $\mathrm{R}$ o g e r s, 1973), the changes in reducing sugars as the main constituents of soluble carbohydrates in chrysanthemums ( $\mathrm{kukaszewska}$, unpublished) were followed in the florets of both cultivars given or not given sucrose in a holding solution.

\section{MATERIAL AND METHODS}

The experiments were carried out in November 1975. Two cultivars were used: 'Bronze Bornholm' and 'Crimson Robe'. The plants were grown single stemmed in a greenhouse at the Municipal Horticultural Farm and the flowers were cut in a bud stage of 50-60 mm in diameter. The stems were trimmed to $50 \mathrm{~cm}$ and put into $500 \mathrm{ml}$ cylinders after having the leaves removed from the lower $20 \mathrm{~cm}$ of stem. A stem bearing an inflorescence and the leaves on upper $30 \mathrm{~cm}$ portion will be referred to as the cut flower in the text. 12 and 10 replications were used for each treatment with 1 flower constituting a single replication for cv. 'Crimson Robe' and cv. 'Bronze Bornholm', respectively. The experiments were performed at room temperature $18-22^{\circ} \mathrm{C}$, air humidity $50-70 \%$ and light intensity about $1000 \mathrm{Lux}$.

The following parameters were measured:

vase-life expressed as a number of days recorded up to the moment when the outer florets wilted or the leaves showed chlorosis and dried up thus decreasing the decorative value of the flowers,

inflorescence diameter expressed as an average of 2 measurements made for each flower of a treatment in two directions separated by $90^{\circ}$,

changes in fresh matter in the wilting flowers as compared to the flower initial weight,

dry matter content in the wilted flowers expressed in per cent after drying the material in $105^{\circ} \mathrm{C}$ to a constant weight,

changes in reducing sugars in the florets.

The sugars were estimated according to Nels on (1944) in $80 \%$ ethanol extracts of fresh florets taken from the outer whorls of inflorescences and expressed in $\mathrm{mg}$ of glucose per gram of fresh and dry matter. The samples for extraction were taken from 10 inflorescences. Three extracts were made for each treatment and three measurements made for each extract.

All data were subjected to analysis of variance, the percentage data being previously transformed according to Bliss and Student t-test was used at $95 \%$ level of probability to evaluate the differences among the 
means. The results of statistical analyses are in the tables where the least significant differences are given or the means which differ significantly are followed by the different letters.

\section{RESULTS}

All the solutions used on cut 'Bronze Bornholm' chrysanthemums increased the flower vase-life. No significant differences were observed between the treatments (Table 1). Placing the chrysanthemums in the solutions of sugar and 8-hydrcxyquinoline sulphate (8-HQS) made the buds open normally (after 3 days) and resulted in a more fult shape of

\section{$\mathrm{Table} 1$}

The effect of sucrose and 8-HQS on vase-life and inflorescence diameter in cut 'Bronze Bornholm' chrysanthemums

\begin{tabular}{|c|c|c|c|}
\hline \multirow[b]{2}{*}{ Solution } & \multirow{2}{*}{$\begin{array}{c}\text { Vase-life } \\
\text { days }\end{array}$} & \multicolumn{2}{|c|}{ Inflorescence diameter } \\
\hline & & $\mathrm{mm}$ & $\begin{array}{l}\% \text { of con- } \\
\text { trol }\end{array}$ \\
\hline Water (control) & $9.3 \mathrm{a}^{*}$ & 88.0 a & 100.0 \\
\hline Sucrose $5 \%$, 8-HQS $200 \mathrm{ppm}$ & $12.8 \mathrm{~b}$ & $116.0 \mathrm{c}$ & 131.8 \\
\hline Sucrose $20 \%$, 8-HQS 200 ppm & $12.5 \mathrm{~b}$ & $108.0 \mathrm{bc}$ & 122.7 \\
\hline Sucrose $20 \%$, 8-HQS 500 ppm & $13.6 \mathrm{~b}$ & $105.0 \mathrm{~b}$ & 119.3 \\
\hline
\end{tabular}

* Means followed by different letters differ significantly at $\mathrm{P}=0.95$.

\section{$\mathrm{Table} 2$}

The effect of sucrose and 8-HQS on dry matter content and changes in fresh weight measured in cut 'Bronze Bornholm' chrysanthemums at the time of wilting as compared to initial weight

\begin{tabular}{lcc}
\hline \multicolumn{1}{c}{ Solution } & $\begin{array}{c}\text { Dry matter } \\
(\%)\end{array}$ & $\begin{array}{c}\text { Changes in } \\
\text { rresh matter * } \\
(\mathrm{g})\end{array}$ \\
\hline Water (control) & $16.9 \mathrm{a}$ & $0.6 \mathrm{a}$ \\
Sucrose 5\%, 8-HQS $200 \mathrm{ppm}$ & $20.2 \mathrm{~b}$ & $4.8 \mathrm{~b}$ \\
Sucrose $20 \%$, 8-HQS $200 \mathrm{ppm}$ & $31.4 \mathrm{c}$ & $7.4 \mathrm{c}$ \\
Sucrose $20 \%$, 8-HQS $500 \mathrm{ppm}$ & $29.8 \mathrm{c}$ & $7.2 \mathrm{c}$ \\
\hline
\end{tabular}

- Weighted as whole: inflorescences on stems $50 \mathrm{~cm}$ long with the foliage left on the upper $30 \mathrm{~cm}$. Average initial weight was $19.5 \mathrm{~g}$. 
inflorescences and an increase in their diameter of $20-30 \%$ as compared to the flowers held in water whose inflorescences were flat and less decorative. The increase in flower longevity and quality caused by the chemicals seems to be due to dry matter accumulation as well as a better water balance in plant tissues as the considerable increases in flower fresh matter were observed in the respective treatments, even at the wilting stage (Table 2). Percentage of dry matter was significantly higher in the flowers held in the solutions of $20 \%$ sucrose than in the treatment with $5 \%$ sugar concentration and nearly doubled in its content as compared to the control flowers.

Placing 'Crimson Robe' flowers in the holding solutions did not result in an increase in flower vase-life (Table 3). In most treatments flowers stayed fresh about 20 days. In two cases a negative sucrose effect was observed: 1) when used alone in the concentration of $5 \%$ it caused wilting of leaves and drying up of outer florets what might have been due to microorganism presence in the conductive tissues as the

Table 3

The effect of sucrose and 8-HQS on vase-life and inflorescence diameter in cut 'Crimson Robe' chrysanthemums

\begin{tabular}{|c|c|c|c|}
\hline \multirow[b]{2}{*}{ Solution } & \multirow[b]{2}{*}{$\begin{array}{c}\text { Vase-life } \\
\text { days }\end{array}$} & \multicolumn{2}{|c|}{ Inflorescence diameter } \\
\hline & & $\mathrm{mm}$ & $\begin{array}{l}\% \text { of } \\
\text { control }\end{array}$ \\
\hline Water (control) & $21.0 \mathrm{~d}$ & $95.0 \mathrm{a}$ & 100.0 \\
\hline Sucrose $5 \%$ & $16.0 \mathrm{a}$ & $98.0 \mathrm{ab}$ & 103.1 \\
\hline Sucrose $5 \%$, 8-HQS 200 ppm & $21.0 \mathrm{~d}$ & $110.0 \mathrm{bc}$ & 115.8 \\
\hline Sucrose $10 \%$, 8 -HQS $200 \mathrm{ppm}$ & $19.8 \mathrm{c}$ & $108.0 \mathrm{bc}$ & 113.7 \\
\hline Sucrose $15 \%, 8$-HQS $200 \mathrm{ppm}$ & $20.4 \mathrm{~cd}$ & $108.0 \mathrm{bc}$ & 113.7 \\
\hline Sucrose $20 \%$, 8 -HQS $200 \mathrm{ppm}$ & $16.0 \mathrm{a}$ & $115.0 \mathrm{c}$ & 121.1 \\
\hline 8-HQS 200 ppm & $20.4 \mathrm{~cd}$ & $106.0 \mathrm{abc}$ & 111.6 \\
\hline $\begin{array}{l}\text { Water - leafless flowers } \\
\text { Sucrose } 10 \%, 8 \text {-HQS } 200 \mathrm{ppm}\end{array}$ & $20.5 \mathrm{~cd}$ & $104.0 \mathrm{abc}$ & 109.5 \\
\hline Leafless flowers & $20.8 \mathrm{~cd}$ & 104.0 abc & 109.5 \\
\hline Intact plants* & $18.4 \mathrm{~b}$ & $101.0 \mathrm{ab}$ & 106.3 \\
\hline
\end{tabular}

* Left in cold greenhouse (only for an approximate comparison).

solution was cloudy and the stem ends became slimy; 2) the chrysanthemums placed in the solution of the highest sucrose concentration $(20 \%)$ remained fully decorative only 16 days because their leaves became chlorotic and dried up.

The presence of sucrose in a holding solution influenced bud opening and flower quality. The inflorescences of chrysanthemums placed in water or in the solution of pure 8-HQS had a flat appearence and 
most of their florets remained unopened until wilting, whereas infloresconces of plants held in the solutions of sucrose and 8-HQS opened after 5 days on the average and were round and full, and tubular florets were visible in the centre. The diameter of inflorescences held in water was on the average $95 \mathrm{~mm}$ while in the chrysanthemums put in the sugar solutions 108-115 mm, no significant differences being observed between the treatments with various sucrose concentrations (Table 3). Flowers given the highest sugar concentration were significantly bigger than those opened on the plants. Removing the leaves off the cut chrysanthemums affected neither flower longevity nor inflorescence diameter. The presence of sucrose in a holding solution increased both fresh and dry weight of the cut 'Crimson Robe' chrysanthemums (Table 4). Flowers held in the solution of $20 \%$ sucrose with

\section{$\mathrm{Table} 4$}

The effect of sucrose and 8-HQS on dry matter content and changes in fresh weight measured in cut 'Crimson Robe' chrysanthemums at the time of wilting as compared to initial weight**

\begin{tabular}{llr}
\hline \multicolumn{1}{c}{ Solution } & $\begin{array}{c}\% \text { dry } \\
\text { matter }\end{array}$ & $\begin{array}{r}\text { Changes } \\
\text { in fresh } \\
\text { matter }\end{array}$ \\
\hline Water (control) & $17.3 \mathrm{bc}$ & $-2.2 \mathrm{a}$ \\
Sucrose $5 \%$ & $19.3 \mathrm{~cd}$ & $3.2 \mathrm{~b}$ \\
Sucrose $5 \%$, 8-HQS $200 \mathrm{ppm}$ & $22.3 \mathrm{e}$ & $7.0 \mathrm{de}$ \\
Sucrose $10 \%$, 8-HQS $200 \mathrm{ppm}$ & $23.7 \mathrm{e}$ & $6.3 \mathrm{de}$ \\
Sucrose $15 \%, 8$-HQS $200 \mathrm{ppm}$ & $28.7 \mathrm{f}$ & $8.9 \mathrm{e}$ \\
Sucrose $20 \%, 8-\mathrm{HQS} 200 \mathrm{ppm}$ & $30.9 \mathrm{f}$ & $6.0 \mathrm{~cd}$ \\
8-HQS 200 ppm & $15.6 \mathrm{~b}$ & $-0.6 \mathrm{a}$ \\
Water - leafless flowers & $12.6 \mathrm{a}$ & $3.5 \mathrm{bc}$ \\
Sucrose $10 \%, 8$-HQS $200 \mathrm{ppm}$ & $19.4 \mathrm{~cd}$ & $6.9 \mathrm{de}$ \\
(leafless) & & \\
Intact plants * & $21.7 \mathrm{de}$ & - \\
\hline
\end{tabular}

- See Table 3.

** Weighed as whole: inflorescences on stems $50 \mathrm{~cm}$ long with the foliage left on the upper $30 \mathrm{~cm}$. Average initial weight $21.1 \mathrm{~g}$.

8-HQS had twice as much dry matter as the flowers put in the solution of 8-HQS alone. The lowest dry matter percentage was found in the leafless chrysanthemums held in water. The flower left intact until wilting had a higher dry matter content than the cut chrysanthemums placed in water.

The changes in the reducing sugars in the florets of the cut 'Bronze 
Ta ble 5

Changes in the reducing sugars in the florets of the cut 'Bronze Bornholm' chrysanthemums held in the solutions of sucrose (S) and 8-HQS

Time of

Solution

extraction

Water (control) S 5\%+8-HQS $200 \mathrm{ppm}$ 'S 20\%+8-HQS $200 \mathrm{ppm}$

mg glucose/g fresh weight

\begin{tabular}{rrrr} 
& 18.0 & 18.0 & 18.0 \\
\cline { 2 - 3 } 1st day & 10.8 & 32.8 & 44.7 \\
5th day & 17.0 & 35.7 & 46.5 \\
8th day & 27.0 & 35.6 & 37.4 \\
\hline 12th day & & & \\
\hline
\end{tabular}

$\mathrm{LSD}=3.2$ at $\mathrm{P}=0.95$

mg glucose/g dry weight

\begin{tabular}{rrrr}
\cline { 2 - 3 } 1st day & 164.6 & 164.6 & 164.6 \\
5th day & 99.4 & 252.8 & 235.2 \\
8th day & 126.5 & 246.1 & 244.0 \\
12th day & 163.5 & 226.4 & 208.8 \\
\hline
\end{tabular}

$\mathrm{LSD}=28.0$ at $\mathrm{P}=0.95$

Bornholm' chrysanthemums are shown in Table 5. In the control flowers sugar levels decreased during the first 4 days and later increased up to or above the initial level, when calculated on the dry or fresh matter basis, respectively. In the flowers placed in sucrose solutions reducing sugars increased and their content at the end of experiment was similar in both treatments, a double of the initial level (calculated per fresh weight).

The changes in the reducing sugars in the florets of the cut 'Crimson Robe' chrysanthemums are shown in Table 6 . In the florets of the flowers held in water and the pure 8-HQS solution small variations in the reducing sugar content were observed and the level of sugars at the time of wilting was similar to that found in the fresh flowers. Using sucrose in the holding solutions made the reducing sugars accumulate in the florets in the amounts several times higher than the initial level. After 11 days a decrease in their content was observed, however, in the wilted flowers their level was still twice as high as that in the freshly cut ones. In the intact chrysanthemums of 'Crimson Robe' cultivar reducing sugars increased almost continuously, reaching the level twice as high as that found at the beginning of experiment. 
Table 6

Changes in the reducing sugars in the florets of the cut 'Crimson Robe' chrysanthemums held in the solutions of sucrose (S) and 8-HQS

Solution

\begin{tabular}{|c|c|c|c|c|c|}
\hline $\begin{array}{c}\text { Time of } \\
\text { extraction }\end{array}$ & $\begin{array}{l}\text { Water } \\
\text { (control) }\end{array}$ & $\begin{array}{l}\text { 8-HQS } \\
200 \mathrm{ppm}\end{array}$ & $\begin{array}{c}\text { S } 5 \% \\
8-\mathrm{HQS} \\
200 \mathrm{ppm}\end{array}$ & $\begin{array}{c}\text { S } 20 \% \\
8-\mathrm{HQS} \\
200 \mathrm{ppm}\end{array}$ & $\begin{array}{l}\text { Intact } \\
\text { plants }\end{array}$ \\
\hline \multicolumn{6}{|c|}{ mg glucose/g fresh weight } \\
\hline 1st day & 12.0 & 12.0 & 12.0 & 12.0 & 12.0 \\
\hline 7 th day & 13.4 & 10.9 & 27.4 & 29.8 & 16.2 \\
\hline 11 th day & 16.0 & 9.5 & 31.9 & 30.9 & 20.7 \\
\hline 14th day & 15.3 & 8.8 & 24.0 & 29.9 & 19.6 \\
\hline 18th day & 14.1 & 13.0 & 21.8 & wilted & 25.2 \\
\hline
\end{tabular}

$\mathrm{LSD}=2.2$ at $\mathrm{P}=0.95$

mg glucose/g dry weight

\begin{tabular}{|c|c|c|c|c|c|}
\hline 1st day & 87.2 & 87.2 & 87.2 & 87.2 & 87.2 \\
\hline 7 th day & 111.3 & 76.5 & 217.5 & 213.1 & 131.2 \\
\hline 11 th day & 141.8 & 89.4 & 215.3 & 214.1 & 158.9 \\
\hline 14 th day & 124.2 & 85.6 & 156.6 & 186.0 & 143.2 \\
\hline 18th day & 106.5 & 90.2 & 131.9 & wilted & 173.3 \\
\hline
\end{tabular}

$\mathrm{LSD}=14.8$ at $\mathrm{P}=0.95$

\section{DISCUSSION}

The buds of both chrysanthemum cultivars opened successfully when placed in the solutions of sucrose plus 8-HQS and were as large as flowers that were opened on the plant confirming the results of Marousky $(1969,1973)$ and Kofranek and Halevy (1972) on different cultivars of standard chrysanthemums. Flowers held in water had diameter $20-30 \%$ smaller than those supplied with sucrose. While the buds of 'Bronze Bornholm' cultivar, which has the medium size inflorescences, opened normally after 3 days when placed in water, the buds of the large-flowered 'Crimson Robe' cultivar held in water or the pure 8-HQS solution did not reach marketable quality. These observations confirm a recommendation to cut chrysanthemums in a stage of full development, otherwise, if no special solutions promoting bud opening are being used, the flowers might not reach full marketable quality.

For the full inflorescence development $5 \%$ sucrose was sufficient and the chrysanthemums did not respond to an increase in the sugar 
dose similarly to the flower response observed by $\mathrm{Glad}$ on and $\mathrm{Staby}$ (1976) in the range of sucrose concentrations from 2 to $16 \%$.

The highest sucrose dose proved to be harmful causing leaf chlorosis and drying up of leaves. This might be a result of an impairment in the osmotic balance due to a build up of sugars before they could be translocated to an inflorescence as was observed in cut roses by Sacalis and Durkin (1972) and Kaltaler and Steponkus (1974), in cut chrysanthem ums by M a rousky (1971) and in cut carnations by $€$ uk a s e wsk a (1978).

Flowers held in the solutions containing sucrose and 8-HQS gained more weight than those placed in water or 8-HQS alone. Sucrose and 8-HQS have anti-dessicant properties (A a ts, 1957; G a y and Nichols, 1977; Stoddard and Hiller, 1962) and 8-HQS controls the microorganisms in a solution as well as prevents physiological blockage in the flower stem (L a rsen and Cromarty, 1967), therefore, both chemicals when used together ensure the state of full turgidity essential for the normal course of life processes in plant. As regards the flower vase-life both cultivars differed in their response to chemicals. Flawers of cv. 'Bronze Bornholm' placed in the sugar solutions lasted 3.5-4 days longer than the control plants whereas 'Crimson Robe' flowers did not respond to exogenous sugar and remained fresh 21 days in most treatments.

In the florets of both chrysanthemum cultivars given the exogenous sucrose reducing sugars increased considerably. In cv. 'Crimson Robe' at the time of wilting their level was twice as high as in flowers not supplied with sucrose and similar to the level found in the intact plants. However, it does not seem likely that in cut chrysanthemums an exhaustion of carbohydrates in the florets is the cause of flower senescence or flower vase-life depends on the amount of reducing sugars. Cultivar 'Bronze Bornholm' having higher initial level of reducing sugars wilted earlier and had more sugars at the time of wilting than cv. 'Crimson Robe' which had a considerably longer life span having a lower initial and final sugar level.

To elucidate a role of exogenously applied sucrose on keeping qualities of cut chrysanthemums more complex studies are needed. The changes in the whole carbohydrate pool in the florets should be followed including also sugars produced and accumulated in stems and leaves.

\section{REFERENCES}

A arts J. F. T., 1957. Over de houdbaarheid van snijbloemen. Med. Landb.

Hogesch. Wageningen, No. 1974: 1-62.

Cywińska-Smoter K., Rudnicki R. $\quad$ M., Goszczyńska $\quad$ D., 1978. 
The effect of exogenous growth regulators in opening tight carnation buds. Scientia Hort. 9: 155-165.

Gay A. P., Nichols R., 1977. The effects of some chemical treatments on leaf water conductance of cut, flowering stems of Chrysanthemum morifolium. Scientia Hort. 6: 167-177.

G la d on R. J., Staby, G. L., 1976. Opening of immature chrysanthemums with sucrose and 8-hydroxyquinoline citrate. Hort. Science 11: 206-208.

Kaltaler R. E. L., Steponkus P. L., 1974. Uptake and metabolism of sucrose in cut roses. J. Amer. Soc. Hort. Sci. 99: 490-493.

Kofranek A. M., Halevy A. H., 1972. Conditions for opening cut chrysanthemum flower buds. J. Amer. Soc. Hort. Sci. 97: 578-584.

Larsen F. E., Cromarty R. W., 1967. Microorganism inhibition by 8-hydroxyquinoline citrate as related to cut flower senescence. Proc. Amer. Soc. Hort. Sci. 90: 546-549.

Łukaszewska A., 1978. Wpływ egzogennych substancji chemicznych na trwałość kwiatów ciętych. Ph. D. Thesis, SGGW-AR, Warszawa.

Marousky F. J., 1969. Influence of various commercial floral preservatives and 8-hydroxyquinoline citrate plus sucrose on development and lasting ability of flower buds of several chrysanthemum cultivars. Proc. Fla. St. Hort. Soc. 82: $398-403$.

Marousky F. J., 1971. Incidence and control of foliar chlorosis on bud-cut chrysanthemums. Hort. Science 6: 298-299.

M a rousky F. J., 1973. Recent advances in opening bud-cut chrysanthemum flowers. Hort. Science 8: 13-16.

Mayak S.; Bravdo B., Gvilli A., Halevy A. H., 1973. Improvement of opening of cut gladioli flowers by pretreatment with high sugar concentrations. Scientia Hort. 1: 357-365.

Nels on A., 1944. A photomeric adaptation of the Somogyi method for determining glucose. J. Biol. Chem. 153: 375-380.

Rogers M. N., 1973. An historical and critical review of postharvest physiology reseasch on cut flowers. Hort. Science 8: 3-6.

Sacalis J. N., Durkin D., 1972. Movement of $\mathrm{C}^{14}$ in cut roses and carnations after uptake of $C^{14}$ sucrose. J. Amer. Soc. Hort. Sci.' 97: 481-483.

Stoddard E. M., Miller P. M., 1962. Chemical control of water loss in growing plants. Science 137: 224-225.

\title{
Wpływ sacharozy i siarczanu 8-hydroksychinoliny na trwałość i jakość kwiatów złocieni ciętych w stadium pąka oraz na poziom cukrów redukujących w kwiatach języczkowych
}

\author{
Streszczenie
}

Zlocienie cięte $\mathrm{w}$ pąku o średnicy 50-60 mm i przetrzymywane $\mathrm{w}$ roztworach sacharozy z siarczanem 8-hydroksychinoliny dorównywały jakością kwiatom nie ciętym, które rozwinęly się na roślinach i byly większe, niż u zlocieni przetrzymywanych w wodzie. Egzogennie podana sacharoza zwiększyła trwałość kwiatów odmiany 'Bronze Bornholm', ale nie wplynęła na odmianę 'Crimson Robe'. Nie obserwowano różnic w jakości kwiatów umieszczonych w roztworach o różnych stężeniach sacharozy. Wszystkie roztwory, które zwiększyły dekoracyjność złocieni, powodowały wzrost świeżej i suchej masy kwiatów. W kwiatach języczkowych złocieni przetrzymywanych w roztworach sacharozy obserwowano wzrost zawartości cukrów redukujących powyżej poziomu stwierdzonego w momencie cięcia pąków. 